\title{
The Role of Logistics in Industrial Side Stream Utilisation - Case: Aqueous Paint Sludge
}

\author{
Tero Leppänen \\ University of Oulu, Finland \\ tero.leppanen@oulu.fi
}

\section{Pasi Rönkkö}

University of Oulu, Finland

pasi.ronkko@oulu.fi

\author{
Harri Haapasalo \\ University of Oulu, Finland \\ harri.haapasalo@oulu.fi \\ Pekka Tervonen \\ University of Oulu, Finland \\ pekka.tervonen@oulu.fi
}

Purpose: In this article, the utilisation of a case side stream, aqueous paint sludge is studied in accordance with the principles of the circular economy. The study's main objective is to find new potential utilisation possibilities for aqueous paint sludge generated in the region and take a closer look at the role of logistics in the industrial side stream utilisation-based business cases and value chains.

Study design/methodology/approach: In this article, the utilisation of aqueous paint sludge is studied via a descriptive case study in the context of Northern Ostrobothnia, Finland. The current state of the paint sludge problem was analysed by interviewing five company representatives. In addition, a workshop was organised, and before the workshop, a questionnaire was sent to all invited.

Findings: As a result, the most feasible solutions for aqueous paint sludge utilisation were identified and evaluated from economic, technical, and environmental points of view in the context of this study. In all the proposed solutions, one general challenge was the logistics for narrow material flows from decentralised sources in a relatively large geographical area.

Originality/value: Prior case studies of paint sludge utilisation as a raw material have been conducted, but the logistics have not played a significant role in the studies. Logistics has been an important part of the circular economy in the literature. This study reaffirms this notion and finds logistics to have an important and decisive role in industrial side stream utilisation-based business cases and value chains.

Keywords: Circular economy, logistics, industrial side stream, industrial by-product

\section{Introduction}

The circular economy has become an increasingly visible part of society. Even though the circular economy is seen as an environmentally friendly approach, its benefits are limited to issues related to the environment and the economy (Ellen McArthur Foundation, 2013; Lewandowski, 2016; Wijkman \& Skånberg, 2015). The list of the benefits of the circular economy is long and diverse, including being a competitive factor for the companies involved, creating employment, and being a driver of economic growth (Wijkman \& Skånberg, 2015).

Well-being has traditionally been related to constant economic growth based on a linear "takemake-waste" economy, but the scarcity of natural resources is becoming a limiting factor for that line of thinking (Van Buren et al., 2016; Ellen McArthur Foundation, 2013). The circular economy is seen as a potential solution to the challenges of the linear economy and for the equation of constant economic growth and limited natural resources (Bocken et al., 2016; Van Buren et al., 2016). Most circular economy solutions utilising industrial side streams are formed 
around the strongest locomotives of the economy, typically heavy industries, where the volume of side streams or waste is the highest (Bocken et al., 2016; Orko, 2020).

In this article, the utilisation of a case side stream, aqueous paint sludge, in accordance with the circular economy principles is studied. Paint sludge is a type of paint waste generated in industrial painting processes. Paint sludge is considered hazardous waste that is typically disposed of by landfilling or by incineration. However, by disposing of the paint sludge, potentially usable resources are lost, and costs from the disposal ensue. Therefore, this article studies the option to utilise paint sludge as a valuable raw material instead of disposing of it.

Examining different aspects of the circular economy and industrial side stream utilisation, this study focuses particularly on the logistics related to circular economy value chains and business ecosystems. Case studies of paint sludge utilisation as a raw material have been conducted earlier (e.g., Burande, 2017; Salihoglu \& Salihoglu, 2016), but the logistics have not played a significant role in the studies. This is the research gap this paper aims to fill, and thus the following two research questions are set for this study. 1) What is the role of logistics in industrial side stream utilisation? 2) What are the greatest challenges in the utilisation of the case side stream?

\section{Literature review}

\subsection{Circular economy}

The circular economy is a relatively new concept that has gained a lot of popularity in recent years (e.g., Bocken et al., 2016; Korse et al., 2016; Schulte, 2013; Kirchherr et al., 2017; Urbinati et al., 2017) and according to Van Buren et al. (2016) it can be seen as "the latest stage in the evolutionary debate on sustainability". The circular economy has many ecological and economic benefits, such as the efficient resource utilisation of materials, environmental friendliness, and energy effectiveness (Deloitte, 2016; Lewandowski, 2016; Stahel, 2016; Sitra, 2016). The circular economy also serves as a platform for more sustainable economic growth and creating employment (Wijkman \& Skånberg, 2015).

The circular economy takes a lot of its inspiration from nature, where no waste exists as everything is merely a resource for other organisms in the ecosystem (Bocken et al., 2014; Schulte, 2013; Stahel, 2016). Whereas in a traditional linear "take-make-waste" economy, products are discarded as waste after use (Van Buren et al., 2016; Stahel, 2016), the circular economy aims to lengthen the lifecycle of products, maximising their value creation and minimising waste generation by maintaining the utility of the resources within the economy (Korse et al., 2016; Schulte, 2013; Urbinati et al., 2017).

In the circular economy, waste is eliminated through product and production designs (Bocken et al., 2016; Lewandowski, 2016). Materials circulate peripherally during the lifecycle of products so that hardly any waste or emissions are generated during the process (Ellen McArthur Foundation, 2013). In terms of product design, the amount of virgin raw materials used in the manufacturing processes is minimised (Van Buren et al., 2016). The products are designed to be easily recycled at the end of their lifecycle (Stahel, 2016). They are manufactured using sustainable materials which can be returned to the biosphere (Ellen McArthur Foundation, 2013). Circular economy production systems are designed to enable the return and repair of products without the costs and disturbances it causes in optimised linear systems (Schulte, 2013). The circular economy also has some unique business models related to reverse logistics and the return of products to the manufacturer (Van Buren et al., 2016). Even though the circular economy can be seen as a superior alternative to the linear economy, Van Buren et al. (2016) 
note that poorly designed circular economy systems are not better than linear economy systems, for example, if the excessive use of logistics or energy is required.

\subsection{Waste and industrial side streams}

The European Waste Framework Directive 2008/98/EC defines waste as "any substance or object which the holder discards or intends or is required to discard" and a by-product as "a substance or object, resulting from a production process, the primary aim of which is not the production of that item." A by-product is not waste if "(a) further use of the substance or object is certain; (b) the substance or object can be used directly without any further processing other than normal industrial practice; (c) the substance or object is produced as an integral part of a production process, and (d) further use is lawful, i.e. the substance or object fulfils all relevant product, environmental and health protection requirements for the specific use and will not lead to overall adverse environmental or human health impacts." (European Union, 2008) In our definitions, these materials discussed here are industrial side streams that only become byproducts once they are productised into repeatable and standardised products.

The directive 2008/98/EC also presents a hierarchy of waste management options that are from the most to least favourable: prevention, preparing for re-use, recycling, another recovery (e.g., energy recovery), and disposal. Waste should be disposed of only if higher priority options are not technically or economically possible. (European Union, 2008) According to Stahel (2016), the viability of the waste management option is related to the resources needed. When a product is re-used, minimal effort is needed to process the product, whereas, in recycling, the amount of the required resources is significantly higher (Stahel, 2016). Directive 2018/851 makes amendments to Directive 2008/98/EC. It encourages member states to take appropriate measures to recognise by-products better to promote the circular economy, sustainable use of resources and industrial symbiosis (European Union, 2018).

\subsection{Business ecosystem and industrial symbiosis}

A business ecosystem is a dynamic structure that consists of an interconnected network of companies, organisations, and other stakeholders, including suppliers, distributors, customers, competitors, and government agencies who create value through cooperation and competition (Moore, 1993). The core concept of a business ecosystem and nature's ecosystem is the same. Ecosystems have different actors creating value together with dynamic and non-linear interaction between them, and just like in nature, the exact boundaries of ecosystems are hard to define. (Kandiah \& Gossain, 1998, Iansiti \& Levien, 2004; Wieland et al., 2012) However, a healthy business ecosystem offers stable relationships and value creation to its members, and it can evolve and renew itself to survive, just like ecological ecosystems (Iansiti \& Levien, 2004; Moore, 1993).

In circular economy business ecosystems formed around industrial side stream utilisation, the central actors are usually the strongest locomotives of the economy, usually heavy industries, generating significant amounts of side streams. This company at the centre can concentrate on its core business and let other companies in the ecosystem utilise the produced side streams as raw materials. These companies form an industrial symbiosis with the side stream producer with mutual benefits. (Van Buren et al., 2016; Orko, 2020) According to Chertow (2000), industrial symbiosis is a form of close cooperation between actors in a business ecosystem. It involves exchanging materials, energy, water and/or side streams enabled by physical proximity. For example, Van Buren et al. (2016) mention the importance of business ecosystems in circular economy solutions and state they are necessary to bring different companies and other stakeholders together for effective side stream utilisation. 


\subsection{Business case analysis}

A business case analysis is a method used to evaluate the feasibility of different business propositions, both qualitatively and quantitatively. The benefits, costs, and risks of proposed projects can be evaluated with a business case analysis. The company can focus its limited resources on the most valuable projects based on the analysis. Implementing projects without an adequate analysis means company resources may be used that could have been better used elsewhere. (Kinnunen et al., 2011) According to Berghout and Tan (2013), one key benefit of a proper business case analysis is the identification of unviable projects before a lot of resources are committed to them. According to Kinnunen et al. (2011), business case analysis consists of a market assessment, technical assessment, financial analysis, strategic fit, and decision-making evaluation.

A market assessment deals with issues such as customer needs, the opportunity window, the size of the market, and competition. A technical assessment deals with the technical feasibility of the proposition and the required resources to implement it. Financial analysis provides a quantitative value for the economic feasibility of the proposition based on the market and technical assessment. Lastly, before decision-making, the strategic fit of the proposition is evaluated, which means considering whether the proposition is in line with the company's strategy and, for example, how a proposed new product fits into the company's product portfolio. (Kinnunen et al., 2011)

\subsection{Logistics}

The concept of logistics consists of controlling forward and reverse flows of goods, services, and information between the point of origin and the point of consumption so that the right product is at the right place at the right time and in the right condition (Bartolacci et al., 2012; Uckelmann, 2008). Logistics can be a significant part of the cost structure for products, and lowering the logistics cost is usually one of the first places potential savings are sought. The logistics costs consist mainly of warehousing and transportation costs, including raw material transportation from suppliers to manufacturers, processing of the materials, transportation from production to a warehouse, the costs of warehousing, and transportation costs from the warehouse to the customer (Fahimnia et al., 2011). Planning and optimisation are closely related to logistics and achieving economic benefits, but emissions are another important aspect of logistics. Polluting fossil fuels are still used in contemporary transportation modes, and other forms of emissions are also generated. Therefore, optimising logistics strategies can achieve higher cost-efficiency, effectiveness, and environmental sustainability (Bartolacci et al., 2012).

Reducing logistics emissions has a vital role in preventing global warming and other harms to nature and the environment. Road transportation especially causes emissions, noise, and traffic congestion (Zheng \& Zhang, 2010), but it is usually the most flexible and necessary part of almost every supply chain. The common utilisation of a transportation fleet is one way to reduce emissions and raise the amount of transported quantity of freight. This usually means outsourcing the logistics to a third-party provider that may transport the goods of several producers simultaneously. This leads to a higher utilisation rate of the fleet, which directly affects fuel consumption and the generation of emissions. (McKinnon, 2010; Zheng \& Zhang, 2010) Considering emissions and fuel consumption is important in circular economy solutions due to their environmentally friendly nature. As mentioned earlier, circular economy solutions may be worse than well planned linear economy solutions if excessive usage of fuel or energy occurs (Van Buren et al., 2016).

When planning new business cases and value chains, logistics and material flow need to be considered from the very beginning when determining locations for different operations (Porter, 
1985; Zhao, 2014). This is critical in typical circular economy solutions, where companies utilising side streams should be close to the producers of the side streams (Orko, 2020). Logistics is an essential part of the circular economy because transporting materials is almost always a requirement for the circular economy (Sitra, 2016). The circular economy principles comprise also returning the products to the manufacturer (Lewandowski, 2016). The feasibility of reverse logistics depends on the length of transportation, the amount of transported materials, and the cost of the processing (Fahimnia et al., 2011).

\section{Materials and methods}

The research process started with an extensive literature review on the circular economy and industrial side stream utilisation and related subjects such as business ecosystems, industrial symbiosis, value chains, business case analysis and logistics. Additionally, prior research on paint sludge utilisation was studied. In this article, the utilisation of aqueous paint sludge is studied via a descriptive case study (Yin, 2014) in the context of Northern Ostrobothnia, Finland. Multiple large-scale national wood product manufacturers are in the region, and their interest in this study was to find alternatives to the costly disposal of paint sludge. Companies producing paint sludge side streams, potential utilisers of paint sludge, other companies in the related value chains, and regional development companies were involved in the empirical study. The scope of this research was narrowed down to only studying aqueous paint sludge as it was thought to have better utilisation potential due to containing fewer environmentally harmful substances. In addition, the use of aqueous paint is increasing.

In the empirical analysis, the chemical composition of paint sludge identified different utilisation possibilities for the paint sludge, their economic, technical, and environmental feasibility, and their business potential were studied. Many other solutions have been proposed based on the literature review on paint sludge utilisation (e.g., Burande, 2017; Gautam et al., 2010; Muniz et al., 2003). Some have only been tested in laboratory conditions (Muniz et al., 2003) but some are already widely used in certain parts of the world (Gautam et al., 2010). However, none of them is reportedly used in the geographical area of this study. The composition of three dewatered paint sludge samples from different sources was analysed by XRF analysis to understand the material's suitability for various utilisation possibilities. Most of the solutions proposed in this study were found from the existing literature (Burande, 2017, Gautam et al., 2010; Salihoglu \& Salihoglu, 2016), but some were innovated by the researchers based on the chemical compounds found in paint sludge samples.

The current state of paint sludge generation was analysed by interviewing five company representatives. The interviews were informal and semi-structured, and of the five companies interviewed, three were wood processing companies such as sawmills and window and door frame manufacturers which were generating aqueous paint sludge in their painting processes, one was a technology provider in the potential value chains of paint sludge utilisation, and one was a regional development company. Furthermore, related to the most potential paint sludge utilisation option identified, one paint manufacturer company representative was interviewed to gain their insight into the technical feasibility of the utilisation option and to gauge their interest in going further with it. In addition, a workshop was organised with 12 participants where a multidisciplinary group of researchers, industry experts and company representatives involved in the study innovated new paint sludge-based products and solutions and evaluated their business potential, costs, feasibility, and practicality in the context of the geographical characteristics present at the country and region this study was conducted in. Before the workshop, a questionnaire was sent to all invited to gain more insight into the current state of the paint sludge problem in the region. The results of the questionnaire (seven answers) served as the basis for the workshop. 
As a result, the most feasible solutions for aqueous paint sludge utilisation were depicted, and some calculations about the cost of logistics were made for the most potent option identified. In all the proposed solutions, one general challenge was the logistics for narrow material flows from decentralised sources in a relatively large geographical area. This prompted this study to look at the role of logistics in the industrial side stream utilisation-based business cases and value chains. Lastly, the results of this study were evaluated from the point of view of how they could benefit the industrial side stream utilisation phenomenon. The most important lessons learned were identified, and the research questions were answered. Figure 1 illustrates the research process, research questions, used research methods and materials.

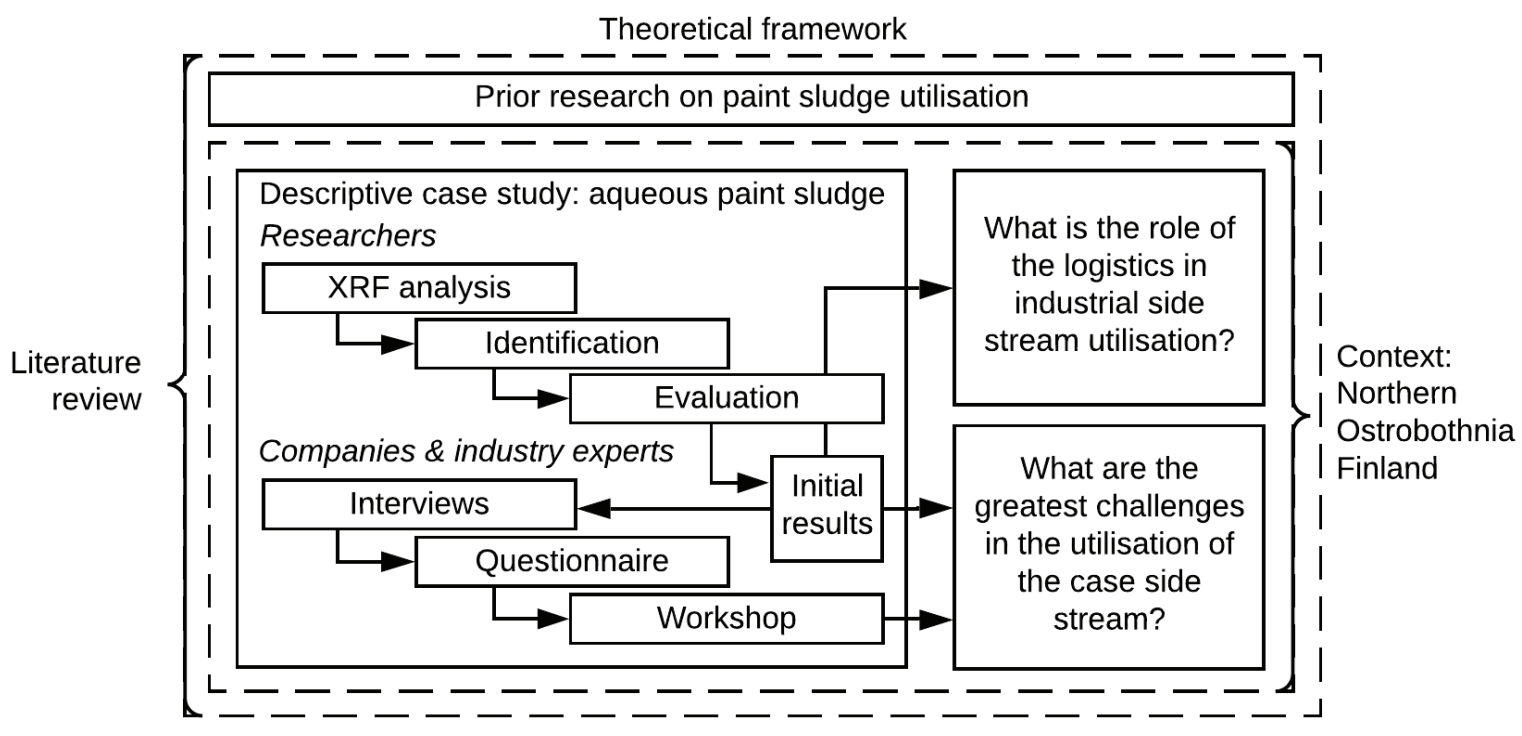

Figure 1: Research process, research questions and research methods used

\section{Results}

\subsection{Paint sludge utilisation in literature}

Paint sludge is a type of paint waste generated in industrial painting processes. Paint sludge is considered hazardous waste and is typically disposed of by landfilling or by incineration. If paint sludge is incinerated, the volume of the remaining ash is roughly $10 \%$ of the original volume, but due to its harmful compounds, it still needs to be landfilled. However, in both methods of disposing of, the resources used to manufacture the original product are lost. (Salihoglu \& Salihoglu, 2016)

In the literature, paint sludge is usually recommended to be utilised as a raw material for new paints, but this can be problematic due to altering material features, such as the chemical composition and colour. Therefore, the utilisation of liquid paint sludge as a raw material in construction materials, such as concrete, cement, mortar, and asphalt, has also been studied. In these solutions, liquid paint sludge can be used to replace the water used in a manufacturing process without significantly affecting the properties of the final product. (Burande, 2017; Salihoglu \& Salihoglu, 2016)

One tested method of processing paint sludge is pyrolysis. Pyrolysis is a chemical reaction executed by burning the material in oxygen-free circumstances. In this reaction burning liquid, gas, and inert solid materials can be produced. The amount of waste is also reduced to onefourth of the original amount. (Muniz et al., 2003; Rosli et al., 2018) Cement kiln incineration is an already used method for disposing of paint sludge. In this method, paint sludge binds into 
cement and may work as a fuel as well. The toxic emissions are neutralised when reacting with other incinerated materials. (Gautam et al., 2010; Tiwary et al., 2014) An experimental method for utilising paint sludge is to use it in chemical catalysts. Paint sludge includes significant amounts of aluminium, titanium, and silicon, and all were tested for this purpose with relatively good results (Romar et al., 2016).

\subsection{Chemical composition of paint sludge}

The composition of the paint sludge was determined by XRF analysis, the main results of which are shown in Table 1. According to the analysis, paint sludge contains roughly 25-30 different components, the most common of which are carbon, aluminium, titanium, and silicon in oxide forms. The contents are presented as a percentage of the dewatered paint sludge samples. Therefore, the less significant raw materials are not shown in the table.

Table 1: The main results of the XRF analysis of three different samples (\% of the material)

\begin{tabular}{|l|l|l|l|l|l|l|l|l|ll|l|l|}
\hline Sample & C & TiO & Al O & SiO & CaO & Na O & S & Cl & P O & Zn & Ba \\
\hline $\mathbf{1}$ & 31.10 & 10.83 & 23.66 & 6.55 & 0.88 & 3.20 & 2.00 & 1.33 & 0.04 & 0.17 & 0.03 \\
\hline $\mathbf{2}$ & 42.20 & 18.85 & 7.43 & 5.34 & 0.94 & 1.27 & 0.67 & 0.03 & 0.11 & 0.00 & 0.01 \\
\hline $\mathbf{3}$ & 23.00 & 21.94 & 18.94 & 9.85 & 7.29 & 1.61 & 1.00 & 0.06 & 0.11 & 0.01 & 0.01 \\
\hline Average & $\mathbf{3 2 . 1 0}$ & $\mathbf{1 7 . 2 1}$ & $\mathbf{1 6 . 6 8}$ & $\mathbf{7 . 2 5}$ & $\mathbf{3 . 0 4}$ & $\mathbf{2 . 0 3}$ & $\mathbf{1 . 2 2}$ & $\mathbf{0 . 4 8}$ & $\mathbf{0 . 0 8}$ & $\mathbf{0 . 0 6}$ & $\mathbf{0 . 0 2}$ \\
\hline
\end{tabular}

\subsection{Analysis of the current state of the paint sludge problem}

According to interviewed experts and answers from companies, it is estimated that roughly 300 tons of aqueous paint sludge are generated in Finland annually. However, the produced amounts differ according to the size of the company and its painting operations, being roughly 100-600 $\mathrm{kg}$ per week. First, the paint sludge is dewatered using chemicals, which mainly consist of aluminium salts, and the remaining still slightly moist and pliable paint sludge bricks are stored and then eventually transported for disposal.

A common way of disposing of generated paint sludge is to deliver it to the nearest waste management facility certified to dispose of hazardous waste. According to the questionnaire answers, the frequency companies deliver paint sludge for disposal usually varies between one to four times a month. Some companies disposed of the paint sludge fewer times a year when the disposed of amounts were naturally higher, in one case up to 10 tons per delivery.

According to company answers, the cost of disposing of one kilogram of paint sludge varied between $0,5-1,2 €$ depending on the amount of paint sludge produced and the frequency paint sludge is transported for disposal. The properties of the paint sludge, such as the colour and chemical composition, varies according to the used paint. Tens of different paints may be used in one company. Sludges of different paints are not separated in the collecting process, and thus the bricks of paint sludge are usually a heterogeneous mixture of different types of paint sludge.

\subsection{Options for paint sludge utilisation}

The following options for paint sludge utilisation were chosen for further evaluation due to the presumed suitability of the material and hypothetical benefits:

- $\quad$ Separating components from paint sludge

- Using paint sludge as an agent for chemical catalysts

- Incineration of paint sludge in a cement kiln

- $\quad$ Utilising paint sludge as a raw material in paints 
The evaluation was based mostly on the presumable technical feasibility, economic benefit, market potential, or other benefits such as environmental friendliness. The solutions of utilising paint sludge in a liquid form, such as using it in construction materials, were abandoned early on due to higher logistics costs compared to solutions utilising paint sludge in dewatered form. The pyrolysis of the paint sludge was not included because the method has only been studied in laboratory conditions. The cost of the industrial-level process of paint sludge pyrolysis was estimated to be economically unfeasible.

\subsubsection{Separating components from paint sludge}

The option to separate rare or valuable components from paint sludge was studied. These materials of interest were especially barium, titanium dioxide, as well as aluminium. According to the results of the XRF analysis, paint sludge contains 10-20\% titanium dioxide and aluminium each, whereas the barium content was only $0.016 \%$ on average. The barium content of paint sludge was thought to be higher initially, but after the XRF results, this option was ruled out. In addition, according to interviewed chemistry experts, barium is a very inert material that is hard and expensive to separate from the sludge in the first place. The separation of aluminium and titanium oxide is more feasible because of their relatively high content in the paint sludge. However, the separation of each component may demand unique processes and investments in new technology. Therefore, even if valuable components can be separated successfully from the paint sludge, economies of scale may not be achieved. In addition, the costs of separation, investments in new technology, and logistics would make operations unfeasible. Because of these factors, this option to utilise paint sludge was deemed unfeasible.

\subsubsection{Paint sludge as an agent for chemical catalysts}

The most experimental solutions chosen for further evaluation were to utilise paint sludge as an agent for chemical catalysts. Catalysts are materials used to speed up or slow down chemical reactions without taking part in them. Catalyst agents are cheap and inert materials to which the actual catalysts are attached, but they may also work as catalysts themselves. (Romar et al., 2016) Especially aluminium, silicon, and titanium have been tested as support agents in cobalt catalysts which can be used, for example, in the Fischer-Tropsch reaction (Romar et al., 2016). This is a relatively high-value option to utilise paint sludge. According to Romar et al. (2016), the Fischer-Tropsch reaction in the catalytic conversion of synthesis gas is an interesting opportunity to produce transportation fuels.

The basis of the utilisation is the high concentration of the components mentioned earlier. According to the XRF analysis, the contents of aluminium (Al $\mathrm{O}$ ) and titanium ( $\mathrm{TiO}$ ) are roughly $17 \%$, and silicon content is approximately $7 \%$ of the paint sludge. However, these components have been tested individually for this purpose and not yet as a mixture which would be the case if dewatered paint sludge were to be used as an agent for a catalyst. Furthermore, paint sludge contains several other components as well, which may inhibit the reaction. Therefore, further research on this front is required.

\subsubsection{Incineration of paint sludge in a cement kiln}

Incineration in cement kilns is an already used method of paint sludge disposal in some countries, e.g., in Turkey, almost two-thirds of cement kilns are licensed to receive paint sludge (Salihoglu \& Salihoglu, 2016), and the first country using cement kiln co-processing was India in 2005, which has a large number of cement kilns (Tiwary et al., 2014). However, in Finland, where this study was conducted, the method seems not widely recognised. 
With this method, paint sludge can be disposed of effectively because the sludge is used both as a fuel and as a replacement for virgin raw materials, such as limestone. Harmful emissions such as acidic gases are not generated during the incineration because they are neutralised due to the alkaline nature of the cement (Tiwary et al., 2014). Paint sludge in a dewatered form includes aluminium salts used for dewatering purposes in addition to the components of the paint sludge itself. At least the properties of aluminium sulphate in cement have been studied, and reportedly it shortens the setting time of the cement and improves the early strength. The negative effects are that it weakens the late strength of the cement and reduces the fluidity. (Kan et al., 2013) The benefit of this method is the total disposal of the paint sludge. Even though the incineration of waste is not one of the more favourable options in the waste handling hierarchy, and the resources used to manufacture the original paint product are lost, this method has its advantages compared to traditional, currently in place ways of paint sludge disposal. This is because presumably, the processing of paint sludge is not needed, and thus all the costs purely arise from logistics. However, because the amount of paint sludge generated yearly is relatively small in Finland, the benefits from replacing some of the raw materials and fuels used in cement manufacturing can be considered marginal. In the context of this study, this option to utilise paint sludge was deemed to be feasible but of low value.

\subsubsection{Paint sludge as a raw material in paints}

One potential solution to utilise paint sludge is to use it as a raw material in paints. In this method, paint sludge can be processed to create a relatively high-value product. However, most prior studies on this subject consider the utilisation of paint sludge in liquid instead of its dewatered form (e.g., Burande, 2017). The properties of the paint sludge, such as the colour and its chemical compounds, depend on the used paint. Because different paints are not separated, the paint sludge ends up being heterogeneous. This is a limiting factor, especially for the colour options of the recycled paint. The chemicals used to dewater paint sludge may be problematic as well. Some additives and pigments are also needed to process the recycled paint into a satisfactory quality. More research is required on the technical feasibility of this option.

If a large paint manufacturer were to start manufacturing a new circular paint product made from paint sludge, they would have distribution and marketing channels for their products already in place. However, the new circular paint product's market potential is questionable and depends on the properties of the end product. For example, what customer segment would the product serve: are the potential customers industrial painting companies or individuals with lower quality needs for the paint? The paint manufacturer should also evaluate how the new circular paint product fits its product portfolio and company strategy. Besides the technical feasibility, the main challenge would be the logistics of transporting the sludge to their facility. For example, there are only a few paint manufacturers in Finland, and transporting paint sludge over long distances may not be viable. Despite these challenges, the option to utilise paint sludge as a raw material in paints was deemed the most potential of the identified solutions in the context of this study.

\subsection{Logistics of paint sludge utilisation options}

One general challenge identified in the proposed solutions was the logistics for narrow material flows over a relatively large geographical area. Logistics can play a significant role, especially in business cases where the material flows are very narrow and scattered, which was the case in this study. Relatively small amounts of paint sludge are generated in this study's geographical area, which makes achieving economies of scale challenging. Paint sludge is considered hazardous waste, but it does not require special transporting conditions by law. Therefore, paint sludge can be transported among almost any other transport. However, long-term warehousing 
may cause fermentation of the paint sludge, which may lower the quality of the material. Thus, long-term warehousing of paint sludge in companies' own facilities is not recommended and even has some legislative restrictions.

Each paint sludge utilisation option has multiple scenarios for logistics depending on where the paint sludge is processed, utilised, and collected. In terms of processing, the alternatives are to have paint sludge processed immediately in companies where the sludge is generated, have a joint processing facility for nearby companies generating paint sludge, or have a more centralised paint sludge processing on a regional or national level. In terms of utilisation and collection, the options are similar, and each of these combinations is a balance between the costs of the logistics and paint sludge processing.

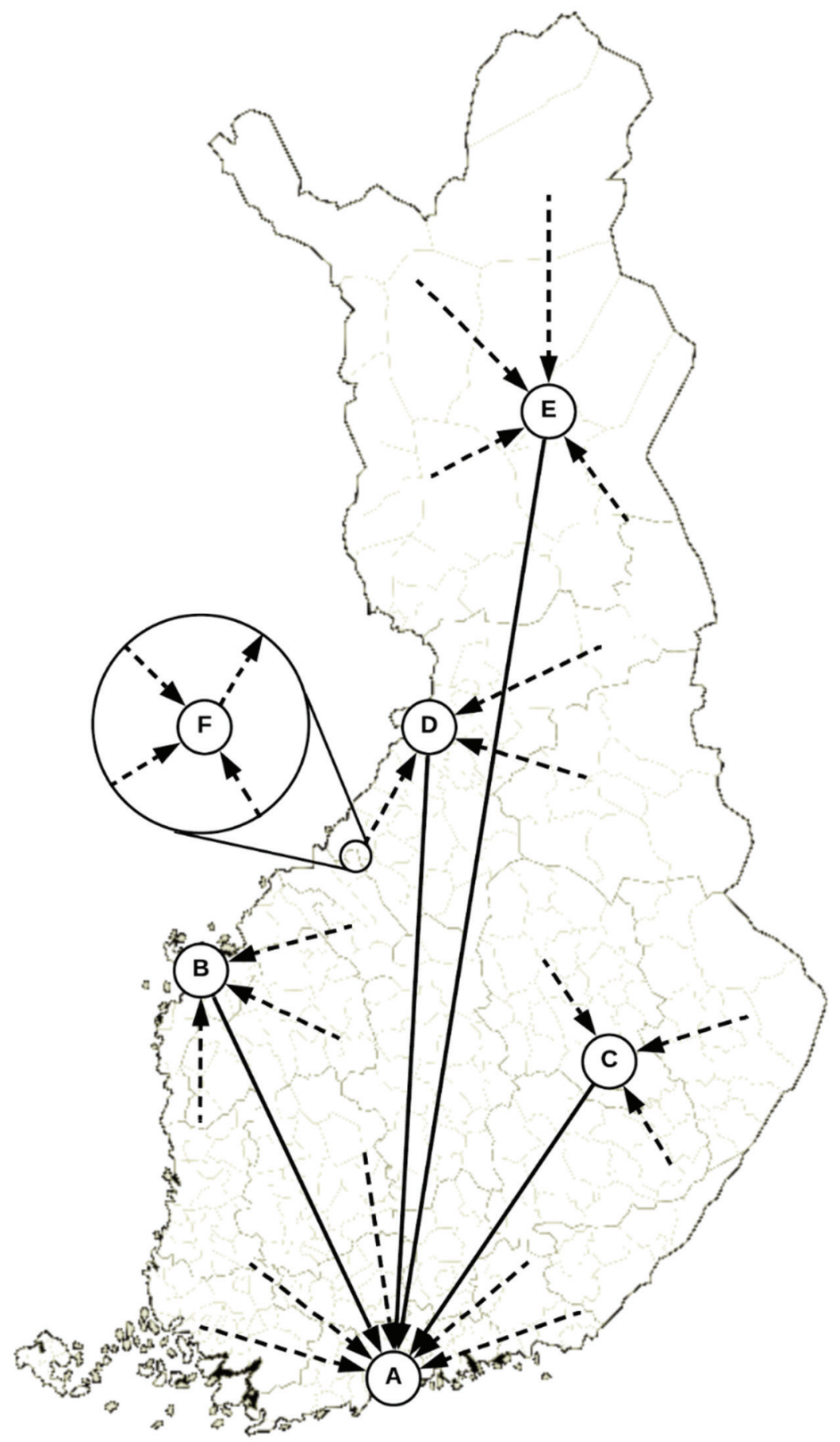

Figure 2: Possible logistics hubs and routes for paint sludge utilisation in Finland 
Figure 2 illustrates the possible logistics hubs and routes for paint sludge utilisation in Finland. In the case of using paint sludge as a raw material in paints, hub A would be a large paint manufacturer's facility where the sludge from the use of their products could be collected from all over the country. Hubs B to E are regional centres, for example, waste management companies, where paint sludge can be collected and then transported to the paint manufacturer. Finally, Hub F represents a local collection centre in a location where there are multiple paint sludge producers nearby.

The option to have paint sludge processed immediately in companies is not feasible. Every company would have to invest in their own processing equipment, which is hardly justified due to the relatively low amount of paint sludge generated on average. Processing paint sludge is not part of their core business. However, the logistics cost would be lowest in this option if the paint sludge were to be utilised locally. In the context of this study, adequate material flows would not be achieved to make local utilisation feasible. The option to collect paint sludge from nearby companies to have it processed in a joint facility and then send it forward to utilisers would lower the processing costs and require less investment in equipment while simultaneously increasing the cost of logistics. In the context of this study, collecting paint sludge from nearby companies and sending it forward is feasible. However, local processing would still need more paint sludge than multiple local companies produce to make it profitable.

In the case of regional processing and utilisation, some sort of middle ground is achieved where the cost of both the processing and logistics are low enough, and the amount of material is adequate to make utilisation feasible. Thus, for example, the option to incinerate paint sludge in a cement kiln could be implemented successfully on a regional level. However, the option to use paint sludge as a raw material in paints would require national-level processing and collection of paint sludge. There are very few paint manufacturers in Finland, and they would need a high amount of paint sludge to make industrial-scale utilisation feasible. In this way, economies of scale could be achieved, but the cost of logistics increases.

\subsubsection{Logistics of paint manufacturer's takeback system}

Using paint sludge as a raw material in paints was deemed to be the most potential utilisation option analysed in this study. However, according to the paint manufacturer's representative, for this paint sludge utilisation option to work, they would have to establish a full-fledged takeback system for residual paint sludge products. Annually, around 300 tons of aqueous paint sludge is generated in Finland, and roughly half of this is from the use of their products. Therefore, to achieve economies of scale and make the manufacturing of a new circular paint product economically viable. Ideally, all the residual paint sludge from their products would have to be transported back to their facilities, meaning organising the annual collection and transportation of 150 tons of paint sludge from very decentralised sources of varying sizes. In Finland, road transportation is the most agile and used transportation method and is currently the method of transporting paint sludge from the companies generating it to disposal sites.

The paint manufacturer is located in the capital area (hub A in Figure 2). In contrast, the majority of manufacturing industries in Finland are located outside the capital area and, for example, the Northern Ostrobothnia region (hub D in Figure 2), where this study took place, has some of the largest paint sludge producers in the country and some municipalities where there are several companies producing paint sludge nearby (hub F in Figure 2). The largest paint sludge producer involved in the study produces roughly 30 tons of paint sludge per year, equalling $10 \%$ of the total estimated amount of aqueous paint sludge produced in Finland annually. This company in question is located 100 kilometres from the centre of hub D. If all the hubs in Figure 2 are expected to collect paint sludge from a 200-kilometre radius, this initial transportation distance can be considered quite average. The secondary transportation distance 
from hub D to A is around 600 kilometres. For all the paint sludge produced, the average secondary transportation distance is estimated to be about 400 kilometres when considering the geographical distribution of paint sludge sources in Finland. Thus, the average total distance for paint sludge transportation would be around 500 kilometres.

The largest producer of paint sludge involved in the study pays around $0,48 € / \mathrm{kg}$ for the disposal, not including VAT or cost of logistics. The company transports their paint sludge three times a year in 10-ton batches to a waste management facility certified to dispose of hazardous waste located 200 kilometres away. The cost of related logistics is around $900 €$ per year, meaning the cost of paint sludge disposal for them is $0,51 € / \mathrm{kg}$, not including VAT. Noteworthy is that this larger company in question transports paint sludge for disposal only three times a year, whereas on the other end of the spectrum, some companies involved in the study that do not have the capabilities required by law to store paint sludge in their facilities for long, were transporting their paint sludge in 100 to $200 \mathrm{~kg}$ batches weekly and reported disposal costs as high as $1,2 € / \mathrm{kg}$ not including VAT. The annual savings for this larger company from implementing the paint manufacturer's takeback system would be $30000 \mathrm{~kg}$ times $0,51 € / \mathrm{kg}$ equals $15300 €$. The storage of paint sludge causes additional costs for the company as sludge is stored on average for four months and sometimes even half a year. These costs, however, are likely to stay the same even after the paint manufacturer's takeback system implementation.

The cost of logistics in Finland is relatively high due to, for example, labour costs and fuel prices. If we take the logistics cost for the aforementioned large paint sludge producer's current disposal, we get $900 €$ divided by 30 tons divided by 200 kilometres equals $0,15 € / \mathrm{t} / \mathrm{km}$. With this, a paint manufacturer's takeback system's estimated cost would be $0,15 € / \mathrm{t} / \mathrm{km}$ times 150 tonnes times 500 kilometres equals $11250 €$, not including VAT. This is a somewhat optimistic estimation as companies are disposing of their paint sludge on average much more frequently and in smaller batches than this large paint sludge producer in question, which significantly increases the cost of logistics. Even though paint sludge is considered hazardous waste, it does not require any special transporting arrangements by law. Thus, third-party logistics providers can transport paint sludge among other goods, thus maximising freight quantity. Even if the paint manufacturer could organise the takeback of their products residual paint sludge efficiently and could come to a favourable deal with one logistics company operating nationwide who could take care of all the logistics related to the takeback system, the annual cost of logistics is likely to be at least $15000 €$ not including VAT. In addition, costs from regional waste management companies' storage and handling of paint sludge ensue, meaning the total annual cost is likely closer to $20000 €$, not including VAT. This could still be a reasonable raw material cost if other challenges related to a new circular paint product made from collected paint sludge were to be solved.

Besides the implementation and costs of the takeback system, other questions related to the use of paint sludge as a raw material in a new circular paint product are technical feasibility, cost of processing and what kind of investments must be made. The demand and target customer segment for this new circular paint product are also somewhat unclear. However, there is potential, and the paint manufacturer is considering whether they should look more deeply into this. The implementation of the takeback system provides added benefits and cost savings for their customer, which could allow the paint manufacturer to increase the prices of their main products when such a service element is added to their existing offering, and this might even attract new customers who currently have problems organising the disposal of their paint sludge. The environmental benefits of the takeback system implementation are clear as paint sludge would be fully utilised instead of disposal. If marketed correctly, this could yield a positive reputation in the customers' eyes for both the paint manufacturer and paint sludge 
producers as responsible, environmentally conscious companies. This could have a positive impact on the sales of their consumer products.

\section{Discussion}

The most promising alternatives to utilise paint sludge generated in the region were identified and evaluated from economic, technical, and environmental points of view in the context of this study. The greatest challenges of paint sludge utilisation were identified. In addition, the logistics related to the implementation of the most potential of the identified solutions was analysed in more detail. The current state analysis revealed that the current way of handling paint sludge represents the least favourable options of the waste handling hierarchy, namely recovering energy from waste and landfilling. The circular economy aims to utilise materials at the highest level possible, and in these current options, the resources used to manufacture original paint are lost.

According to the empirical study, the one general challenge for utilising paint sludge as a raw material in this study was related to narrow materials flows resulting from decentralised and relatively small sources of paint sludge. Often circular economy solutions are formed around major industrial companies where the volume of generated side streams is the highest. However, this was not the case for paint sludge utilisation because paint sludge is generated in relatively small amounts in multiple companies scattered all over the country. This results in narrow material flows and long transportation distances, making the economically and ecologically feasible use of paint sludge challenging. The main question was how wide an area would paint sludge have to be collected to make utilisation feasible and achieve economies of scale? Besides other feasibility issues such as the suitability of the material, the technical aspects of processing the material, and the questionable market potential for paint sludge products, the profitability of the evaluated utilisation possibilities for paint sludge are primarily a matter of finding a balance between the costs of processing and logistics and achieving adequate material flows for feasible utilisation. In the context of this study, this would require regional or national-level utilisation of paint sludge.

The main objectives of this study were to find new potential utilisation possibilities for paint sludge and take a closer look at the role of logistics in industrial side stream utilisation-based business cases and value chains. Thus, the main objectives of the study were achieved. However, this study was conducted in Finland, a sparsely populated Nordic country with relatively long distances and low amounts of generated paint sludge. Usually, circular economy solutions are formed around high-volume side streams, which paint sludge is not at least in the context of this study. In some other geographical areas with higher amounts of generated paint sludge and shorter distances between its sources, the proposed solutions that were found to be unfeasible in this study might turn out to be a profitable business in another context. However, in the context of sparsely populated regions, similar challenges related to the logistics of industrial side stream utilisation are likely to emerge. Thus the results of this study can be considered valid in that context. Other limitations in terms of reliability and validity (Saunders et al., 2009) are mostly related to the research process itself. One issue is the relatively small number of interviewed companies generating paint sludge and potential companies to utilise paint sludge in their processes as raw material. There certainly are solutions for the utilisation of paint sludge that were not identified in this study. As further research implications, some of the evaluated solutions still require more research, for example, the option to utilise paint sludge as an agent in chemical catalysts, and a similar study on paint sludge utilisation should be conducted in a more densely populated geographical area to see what other factors are highlighted when the logistics is not a limiting factor. 


\section{Conclusions}

Logistics has been an important part of the circular economy in the literature. This study on paint sludge utilisation reaffirms this notion and finds logistics to have an important and decisive role in industrial side stream utilisation-based business cases and value chains. Therefore, effective planning and coordination of the related logistics are needed for the utilisation to be profitable. Besides the costs, contemporary modes of transportation generate emissions that may negate any environmental benefits from using industrial side streams as raw materials. Poorly designed circular economy solutions may be even worse than the linear economy alternative if excessive logistics are needed. Thus, logistics clearly plays a significant role in creating effective, economically viable and environmentally friendly circular economy solutions, being in some cases the determining factor in the feasibility of the solution. Therefore, in the industrial side stream, utilisation-based business cases, and value chains, a relatively high priority should be placed on planning the related logistics.

\section{References}

Bartolacci, M. R., LeBlanc, L. J., Kayikci, Y., \& Grossman, T. A. (2012). Optimisation Modeling for Logistics: Options and Implementations. Journal of Business Logistics, 33(2), 118-127. https://doi.org/10.1111/j.0000-0000.2012.01044.x

Berghout, E., \& Tan, C-W. (2013). Understanding the impact of business cases on IT investment decisions: An analysis of municipal e-government projects. Information \& Management, 50(7), 489-506. https://doi.org/10.1016/j.im.2013.07.010

Bocken, N. M. P., De Pauw, I., Bakker, C., \& Van Der Grinten, B. (2016). Product design and business model strategies for a circular economy. Journal of Industrial and Production Engineering, 33(5), 308-320. https://doi.org/10.1080/21681015.2016.1172124

Bocken, N. M. P., Short, S. W., Rana, P., \& Evans, S. (2014). A literature and practise review to develop sustainable business model archetypes. Journal of Cleaner Production, 65, 42-56. https://doi.org/10.1016/j.jclepro.2013.11.039

Burande, B. (2017). Utilisation of paint sludge from automotive industries into valuable products. International Journal of Recent Trends in Engineering \& Research, 3(5), 513-519. https://doi.org/10.23883/IJRTER.2017.3257.RPNMG

Chertow, M. R. (2000). Industrial symbiosis: Literature and Taxonomy. Annual Review of Energy and the Environment, 25, 313-337. https://doi.org/10.1146/annurev.energy.25.1.313

Deloitte (2016). Deloitte Sustainability - Circular economy potential for climate mitigation. https://www2.deloitte.com/content/dam/Deloitte/fi/Documents/risk/Deloitte\%20\%20Circular\%20economy\%20and\%20Global\%20Warming.pdf (accessed 24 February 2021)

Ellen McArthur Foundation (2013). Towards the Circular Economy - Economic and business rationale for an accelerated transition. https://www.ellenmacarthurfoundation.org/assets/downloads/publications/EllenMacArthur-Foundation-Towards-the-Circular-Economy-vol.1.pdf (accessed 24 February 2021)

European Union (2008). Directive 2008/98/EC of the European Parliament and of the Council of 19 November 2008 on waste and repealing certain Directives (Text with EEA relevance). Off. J. Eur. Union, 312, 3-30. http://data.europa.eu/eli/dir/2008/98/oj (accessed on 3 December 2020)

European Union (2018). Directive 2018/851 of the European Parliament and of the Council of 30 May 2018 amending Directive 2008/98/EC on waste (Text with EEA relevance). Off. J. Eur. Union, 150, 109-140. http://data.europa.eu/eli/dir/2018/851/oj (accessed on 3 December 2020)

Fahimnia, B., Ebrahimi, H., \& Molaei, R. (2011). Integration in Logistics Planning and Optimization, in: Farahani, R.Z., Rezapour, S., Kardar, L. (Eds.), Logistics Operations and Management (1st ed.). Elsevier, London. https://doi.org/10.1016/B978-0-12-385202-1.00018-9

Gautam, S. P., Bundela, P. S., \& Murumkar, M. (2010). Paint sludge waste co-processing at the ACC Wadi Cement Works in Karnataka, India. WIT Transactions on Ecology and the Environment, 140, 57-66. https://doi.org/10.2495/WM100061

Kandiah, G., \& Gossain, S. (1998). Reinventing value: The new business ecosystem. Strategy \& Leadership, 26(5), 28-33. https://doi.org/10.1108/eb054622

Iansiti, M., \& Levien, R. (2004). Strategy as Ecology. Harvard Business Review, March 2004. https://hbr.org/2004/03/strategy-as-ecology (accessed 24 February 2021)

Kan, C. Y., Lan, M. Z., Kong, L. M., \& Yang, J. (2013). Effect of Aluminium Sulfate on Cement Properties. Materials Science Forum, 743-744, 285-291. https://doi.org/10.4028/www.scientific.net/MSF.743744.285 
Kinnunen, T., Pekuri, A., Haapasalo, H., \& Kuvaja, P. (2011). Business case analysis in new product development. Global Journal of Management and Business Research, 11(2). ISSN: 0975-5853

Kirchherr, J., Reike, D., \& Hekkert, M. (2017). Conceptualising the circular economy: An analysis of 114 definitions. Resources, Conservation \& Recycling, 127, 211-232. https://doi.org/10.1016/j.resconrec.2017.09.005

Korse, M., Ruitenburg, R. J., Toxopeus, M. E., \& Braaksma, A. J. J. (2016). Embedding the Circular Economy in Investment Decision-making for Capital Assets - A Business Case Framework. Procedia CIRP, 48, 425430. https://doi.org/10.1016/j.procir.2016.04.087

Lewandowski, M. (2016). Designing the Business Models for Circular Economy -Towards the Conceptual Framework. Sustainability, 8(1), 1-28. https://doi.org/10.3390/su8010043

McKinnon, A. (2010). Green Logistics: The Carbon Agenda. LogForum, 6(3), 1-9. ISSN 1734-459X

Moore, J. F. (1993). Predators and Prey: A New Ecology of Competition. Harvard Business Review, May-June 1993. https://hbr.org/1993/05/predators-and-prey-a-new-ecology-of-competition (accessed 24 February 2021)

Muniz, L. A. R., Costa, A. R., Steffani, E., Zattera, A. J., Hofsetz, K., Bossardi, K., \& Valentini, L. (2003). A study of paint sludge deactivation by pyrolysis reactions. Brazilian Journal of Chemical Engineering, 20(1), 63-68. https://doi.org/10.1590/S0104-66322003000100012

Orko, I., Ritschkoff, A. C., \& Lantto, R. (2020). Kiertotalouden ekosysteemit. Työ- ja elinkeinoministeriön julkaisuja, 13, 143. ISBN 978-952-327-500-3

Porter, M. E. (1985). Competitive Advantage: Creating and Sustaining Superior Performance (3rd ed.). Weilin+Göös, Espoo. ISBN: 951-35-3548-7

Romar, H., Lillebø, A. H., Tynjälä, P., Hu, T., Holmen, A., Blekkan, E. A., \& Lassi, U. (2016). H2-TPR, XPS and TEM Study of the Reduction of Ru and Re promoted $\mathrm{Co} / \gamma-\mathrm{A} 12 \mathrm{O} 3, \mathrm{Co} / \mathrm{TiO} 2$ and $\mathrm{Co} / \mathrm{SiC}$ Catalysts. Journal of Materials Science Research, 5(2), 33-43. https://doi.org/10.5539/jmsr.v5n2p33

Rosli, N. L., Rahman, N. A., \& Kadri, A. (2018). Methane Synthesis from Automotive Paint Sludge via Microwave Assisted Pyrolysis. Proceedings of the 3rd International Conference on Global Sustainability and Chemical Engineering (ICGSCE), Putrajaya, Malaysia, 15.-16.2.2017. https://doi.org/10.1088/1757$899 X / 358 / 1 / 012029$

Salihoglu, G., \& Salihoglu, N. (2016). A review on paint sludge from automotive industries: Generation, characteristic and management. Journal of Environmental Management, 169, 223-235. https://doi.org/10.1016/j.jenvman.2015.12.039

Saunders, M., Lewis, P., \& Thornhill, A. (2009). Research methods for Business Students (5th ed.). Prentice-Hall. ISBN: 978-0-273-71686-0

Schulte, U. G. (2013). New Business Models for a Radical Change in Resource Efficiency. Environmental Innovation and Societal Transitions, 9, 43-47. https://doi.org/10.1016/j.eist.2013.09.006

Sitra (2016). Leading the cycle - Finnish road map to circular economy 2016-2025. Sitra Studies, 121, 56. ISBN 978-951-563-978-3

Stahel, W. R. (2016). The circular economy. Nature, 531, 435-438. https://doi.org/10.1038/531435a

Tiwary, A., Sharma, G., \& Gupta, P. K. (2014). Quantification of the reduced environmental impacts with use of co-processing in cement kilns in India. Environmental Research, Engineering and Management, 69(3), 516. https://doi.org/10.5755/j01.erem.69.3.6736

Uckelmann, D. (2008). A Definition Approach to Smart Logistics. Proceedings of the Next Generation Teletraffic and Wired/Wireless Advanced Networking, 8th International Conference, NEW2AN and 1st Russian Conference on Smart Spaces, ruSMART 2008, St. Petersburg, Russia, 3.-5.8.2008; Balandin, S., Moltchanov, D., Koucheryavy, Y. (Eds.), Springer Berlin Heidelberg, Berlin. https://doi.org/10.1007/9783-540-85500-2_28

Urbinati, A., Chiaroni, D., \& Chiesa, V. (2017). Towards a new taxonomy of circular economy business models. Journal of Cleaner Production, 168, 487-498. https://doi.org/10.1016/j.jclepro.2017.09.047

Zhao, X. (2014). Based on Gravity Method of Logistics Distribution Center Location Strategy Research. Proceedings of the International Conference on Logistics Engineering, Management and Computer Science (LEMCS 2014), Shenyang, China, 24.-26.5.2014. https://doi.org/10.2991/lemcs-14.2014.134

Wieland, H., Polese, F., Vargo, S., \& Lusch, R. (2012). Toward a Service (Eco)Systems Perspective on Value Creation. International Journal of Service Science, Management, Engineering and Technology, 3(3), 1225. https://doi.org/10.4018/jssmet.2012070102

Wijkman, A., \& Skånberg, K. (2015). The Circular Economy and Benefits for Society - Jobs and Climate Clear Winners in an Economy Based on Renewable Energy and Resource Efficiency. https://s3-eu-west1.amazonaws.com/avfall-norge-no/dokumenter/The-Circular-Economy-and-Benefits-for-Society.pdf (accessed 24 February 2021)

Van Buren, N., Demmers, M., Van Heijden, R., \& Witlox, F. (2016). Towards a Circular Economy: The Role of Dutch Logistics Industries and Governments. Sustainability, 8(7), 1-17. https://doi.org/10.3390/su8070647 
Yin, R. K. (2014). Case Study Research Design and Methods (5th ed.). Sage, Thousand Oaks. ISBN 978-1-45224256-9

Zheng, L., \& Zhang, J. (2010). Research on Green Logistics Based on Circular Economy. Asian Social Science, 6(11), 116-119. ISSN: 1911-2017 